https://doi.org/10.3727/152599521X16288665119396

MS 20080 accepted for publication in Event Management

\title{
What are Convention Attendees Looking for? An Examination of the Impact of Perceived Value and Value Co-creation on Attitude Formation
}

Jie Min Ho, Joseph Kee Ming Sia, Sean Lee, and Ching Seng Yap

Curtin University, Malaysia

\section{Author Note}

Jie Min Ho: https://orcid.org/0000-0001-8881-2393

We have no known conflict of interest to disclose.

All correspondence concerning this article should be addressed to Dr Jie Min, Ho, Curtin University, Malaysia, CDT 250,98009 Miri, Sarawak Malaysia. Email:

jiemin.ho@curtin.edu.my 


\begin{abstract}
Despite convention tourism is becoming an important segment of the tourism industry in many countries, the specific benefits that convention attendees see valuable when attending conventions are inconclusive. Based on the consumption values theory, this study considers the impacts of two types of value: perceived value and value of co-creation on convention attendees' attitude formation. Derived from a sample of 434 convention attendees and Partial Least Squares Structural Equation Modelling (PLS-SEM) analysis, results indicate that value of co-creation, together with another two dimensions of perceived value, emotional value and functional value, have significant influences on convention attendees' attitude towards the convention attended. Particularly, it was found that perceived value by itself had limited effects in contributing the positive attitude towards conventions in the contemporary business world as consumers today are increasingly prefer co-creation of value and collaboration with service providers. The study contributes to the convention tourism literature by being the first to incorporate both perceived value and value of co-creation within the same model and testing related hypotheses. The results may facilitate decision-making and strategic development of tourism-related investments among convention organisers, destination marketing organisations and government agencies, which can eventually strengthen a country's competitive edge in attracting convention attendees.
\end{abstract}

Keywords: Convention, business event, perceived value, value co-creation, attitude. 


\section{What are Convention Attendees Looking for? An Examination of the Impact of Perceived Value and Value Co-creation on Attitude Formation}

Nowadays, convention tourism is becoming more important than ever. Together with meetings and exhibitions, convention hosting generated \$1.07 trillion in direct spending and contributed $\$ 1.5$ trillion of global GDP of 2017 , which would rank it as the $13^{\text {th }}$ largest economy in the world, ahead of economies of several countries, including Australia, Spain, Mexico, Indonesia, and Saudi Arabia (Events Industry Council \& Oxford Economics, 2018). Apart from the lasting economic benefits, convention hosting also enhances a destination's identity and image, facilitates regeneration and pace development, promotes community cohesion and finally leads to the positive effects on the local economy (Dowse \& Fletcher, 2018; Oppermann \& Chon, 1997). Therefore, conventions can be described as the seams of gold (Nelson 2010) that run through the tourism sector and realise the economic benefits of any countries alike. Recognising the benefits associated with hosting conventions, the competition in the sector is on a constant rise (Ahmad \& Daud, 2016; Getz, 2014; McCartney, 2008; Weber \& Ladkin, 2003). Hence, it is paramount for tourism marketers to understand what convention attendees look for and how do they evaluate conventions participated in order to deliver a satisfactory convention experience. From the industry point of view, event operators also need to address and consolidate different strategic issues, such as the increase demand for personalization and customer experience, in order for the hosting destination and event planners to remain competitive.

Despite the growing importance of the convention industry, a few gaps remain. Firstly, the aspects of convention desired and valued by convention attendees are inconclusive. For instance Jung (2011) posited that convention attendees' value is made up of acquisition, emotional, monetary and social values. In another study, Lee and Min (2013) adopted functional, emotional and social values to represent convention attendees' value and 
claimed that each would differently affect the satisfaction. Clearly, the values which contribute to convention attendees' evaluation on a convention as well as the strength of each are still debatable, thereby created grounds for further studies.

Secondly, it has come to our attention that most of the existing studies concerning convention attendee' value perception have forgone the impact of value jointly created by convention attendees and convention planners. With the value of co-creation gaining popularity in the service sector (Anker et al., 2015; Prahalad \& Ramaswamy, 2004a), an examination of consumer value that takes into consideration the value derived from service consumption as well as the value derived from co-creating experience, is required (Hansen, 2019). To the best of our knowledge, no study has attempted to examine perceived value and value of co-creation within the same model, specifically in the convention tourism context. Previously, Prebensen and Xie (2017) found that value of co-creation and perceived value significantly contribute to tourists' satisfaction. However, being one of the very few studies in the field of tourism that suggests tourists' value perception is made up of perceived value and value of co-creation, further studies are needed to confirm the claims. The result of the study cannot be generalized as well since it only took into consideration the mind-set of leisure tourists visiting Norway in 2013. Additionally, travelling for leisure or for business may also result in different value perception and thus, generalising results from this study to future ones that are conducted in a convention tourism context is not appropriate. In view of this, this study serves as the pioneering study that integrates the two constructs in the convention tourism context. Furthermore, an examination of the roles of these two types of values could deepen the understanding of determinants that shape convention attendees' attitude and their subsequent behaviour. Consequently, it would also provide fresh perspectives to the knowledge on consumer behavior. 
Additionally, the existing knowledge and understanding of the needs and wants of convention participants are still, in general, much less developed than other sectors of the tourist industry (Leach et al., 2008; Mair, 2012; 2014). Many of the existing scholarly works are predominantly focus on leisure events (e.g., music festivals) and sports events (e.g., Olympics). Hence, this study extend the body of knowledge by investigating whether convention attendees' value perception would be similar when it comes to convention participation, where attendees are travelling to the hosting destination for professional purposes. This is also a response to the arguments championed by Kim and Kaewnuch (2018) that call for more event management studies focusing on trade and business events that have been understudied.

In sum, the main objective of this paper is to ascertain the effect of convention attendees' value perception on the formation of their attitude towards the convention attended. Specifically, this paper takes into account the impact of three perceived value dimensions (emotional, social and functional values) and value of co-creation when assessing consumer values. To the best of our knowledge, the conceptual model in this study is the first to integrate both perceived value and value co-creation in measuring consumer values and subsequent effect. The inclusion of value of co-creation into the analysis would contribute to the generation of a more holistic finding to understand the inter-relationships within the process of attendees' evaluation and decision-making in the convention tourism context.

\section{Literature Review}

\section{Consumer Value and Consumption Values Theory}

Consumer value has emerged into a crucial pillar in understanding consumer behavior (Kostelijk, 2017; Sweeney \& Soutar, 2001; Zeithaml, 1988) as well as consumer satisfaction in developing customer loyalty (Varki \& Colgate, 2001; Wang et al., 2004). Nonetheless, research on consumer value remains scattered and inconclusive (Russo \& Confente, 2017; 
Sánchez-Fernández et al., 2009; Zauner et al., 2015). This could be due to the difficulties in the conceptualisation of consumer value in many different streams of marketing literature (Beneke \& Carter, 2015; Gonçalves et al., 2016; Sánchez-Fernández et al., 2009). The concept of consumer value has been used interchangeably with terms such as 'customer value', 'shopping value', and 'judgemental value' (Khalifa, 2004) but has, at the same time, been confused with other related constructs including 'values', 'utility', 'price', 'quality' or even 'satisfaction' (Sánchez et al., 2006). For this paper, consumer value is conceptualized based on approach put forth by Holbrook (1999) and Woodall (2003) and viewed as the benefits or advantages that consumers favor over other alternatives,

In predicting consumer behavior, Sheth et al. (1991a) have proposed the consumption values theory that dominates the conceptualisation of consumer perceived value in the marketing literature (Ramayah et al., 2018b; Sánchez et al., 2006). In general, this theory assumes that consumer value may be used to explain consumers' choice to repurchase, purchase or not purchase a product, the choice of one brand over another and the choice of a specific type of product over another. Specifically, the theory of consumption values puts forward that consumers attach multiple values to a product which can affect their satisfaction and ultimately influence their consumer choice (Lin et al., 2015; Ramkissoon et al., 2009). Thus, the researchers have arrived at the consensus that the nature of consumption values is complex and multi-dimensional, rather than a trade-off between benefits and price (Sung \& Ozuem, 2018; Sweeney \& Soutar, 2001). For example, Sheth et al. (1991a) identify five values that influence consumer choice behavior: functional, social, emotional, epistemic and conditional values. It is also important to note that these value dimensions independently and differently contribute to the consumer choice based on consumers' experience and interaction with the product or service (Aamin et al., 2016; Woodall, 2003). According to Sweeney and Soutar (2001), perceived value drives consumers' purchase attitude and subsequent behavior. 
As attitudes are learned (Schiffman et al., 2014), they are shaped and acquired by information received and personal experiences (Wilkie 1994). Meanwhile, they have also proven that perceived value dimensions as the antecedent of attitude, satisfaction and behavior in both pre-purchase and post-purchase situations.

Very little studies have attempted to explain perceptions of travellers using the consumption values theory (Phau et al., 2014). In one relevant study, Phau et al. (2014) recommended the consumption values theory as a useful framework in explaining and understanding travellers' decision and behavior. Their study suggests that only social and conditional values have been found to significantly influence young Australian tourists' intention to visit Mauritius. Along the same line, Choe and Kim (2018) have also applied the consumption values theory to tourists' local food consumption. However, they claimed that modifications of the constructs introduced in the original consumption values theory are required to suit the diverse tourism contexts. In agreement with Sweeney and Soutar (2001) and Choe and Kim (2018) also highlighted the relationship between tourists' consumption values and attitude towards the local food. The researchers also point out that this linkage is considered a strong predictor of a series of consumer behaviors. By the same token, when studying consumption values of gastronomic tourists, Peng et al. (2019) substantiated that restaurant dining experience contributes to tourists' attitude towards a destination. Thus, according to the same rationale, when treated as an experience, convention participation may have a positive influence on business travellers' attitude towards the convention participated. Anyhow, the concept of consumption value is important to the research on convention tourism as they identify the main value-adding elements that business travellers or convention attendees obtain and desire while participating in a convention that requires travelling. Nonetheless, to the best of our knowledge, no research has been designed to explore business travellers' consumption value and their outcomes. Through an examination of existing 
literature, it has also been found that researchers tend to conceptualise consumer value as value creation that is sole decided by organisation - perceived value.

\section{Perceived Value and Attitude towards the Convention}

In recent years, customer perceived value has become an object of interest of many hospitality and tourism industry related research studies (eg., Lee et al., 2014; Mitchell et al., 2016; Peña et al., 2012; Prebensen et al., 2013; Scaglione \& Mendola, 2017). A critical aspect of perceived value is to assist decision-makers to better understand the value-creation process among consumers (Smith \& Colgate, 2007). In doing so, two approaches have gained much popularity in conceptualising perceived value: uni-dimensional and multidimensional. In particular, the uni-dimensional approach offers a basis for value as a function of the utility of a product or service based on perceptions of a trade-off between total benefits and total sacrifices (Weinstein \& Johnson, 1999). This approach is usually measured using selfreported items to reflect cognitive and utilitarian perceptions of value among consumers (Cronin et al., 2000; Zeithaml, 1988). However, concerns have been raised that perceived value is much more complex to be conceptualized as uni-dimensional and solely utilitarian based (Woodall, 2003). Some scholars also postulated that consumers, especially that of tourism, hospitality and leisure industries do not evaluate value based on only the economic

term but a broader view of consumer value with multiple components is needed to holistically interpret and understand a complex phenomenon (Bradley \& Sparks, 2012). According to the multidimensional approach, perceived value is actually the sum of multiple dimensions of value that have differential effects, under different situations (Fandos Roig et al., 2006; Sheth et al., 1991a). Therefore, perceived value is ought to be analysed as a construct composed of multiple variables (Sánchez-Fernández \& Iniesta-Bonillo, 2007). Additionally, Sheth et al. (1991a, 1991b) also noted that consumer consumption pattern is a result of multiple value dimensions making differential contributions. Thus, conceptualising perceived value as a 
multi-dimensional construct is more reliable and has greater interpretability than as a unidimensional construct (Kamakura \& Novak, 1992). In the same vein, Sweeney and Soutar (2001) also regarded multiple value dimensions as better predictors than a single value item. Particularly, multiple hospitality and tourism studies have also provided evidence for perceived value's connection to quality, satisfaction as well as loyalty (Lee \& Min, 2013).

Though there is no consensus when it comes to conceptualising customers' perceived value, previous studies have shown that the perceived value dimensions would generally fall under cognitive, functional and affective aspects of perceived value (Zauner et al., 2015). In addition, all these previous studies also point to the direction that the effect of different perceived value dimensions are differed, probably due to the nature of products or services evaluated. This could be due to that fact that different products and services feature distinctive levels of functional, financial, social, psychological or event opportunity risks that can have an impact on consumers' attitude and behavior (Gupta et al., 2004). In that sense, even though perceived value has been studied in different types of tourism products, a study that focuses on convention attendees' perceived value, which is limited in the literature, is still very much needed.

Ample evidence exists to support the positive influence of perceived value on positive attitude towards service providers (Fiore et al., 2005; Lee et al., 2014; McDougall, 2000; Ruiz-Molina \& Gil-Saura, 2008; Sweeney \& Soutar, 2001). The relationship between perceived value and attitude is also supported by Maggon and Chaudhry (2018) who claim that consumers' attitude is formed by their respective experience with the products or services purchased. Thus, attitude can be seen as the effect of perceived value and antecedent of consumers' purchase intention (Liao et al., 2013). With that being said, merchants and service providers must put in efforts to alter passive consumers' attitude and ensure the quality of their product and service to approach a better attitude. Meanwhile, in the tourism 
context, Ducoffe (1996) posited that a mega event that offers high consumer value will contribute to positive visitors' attitude towards the particular event. In particular, the positive attitude is the result of affective and cognitive evaluations formed through convention participation (Rokeach, 1972; Teo et al., 2003).

Based on the foregoing discussion, it is expected that perceived value of convention attendees will affect their attitude towards the event attended. Following what Lee and Min (2013) have argued, in the convention context as proposed in this study, three dimensions are particularly desired by convention attendees: emotional, social and functional of price values. Meanwhile, the effect of these different dimensions is to be investigated individually (Sheth et al., 1991a). These three dimensions are viewed as essential in which, attendees experience emotional and psychological benefits (emotional value), develop social networks as well as gain peer recognition (social value) through the participation. The convention participation is also expected to involve substantial travel costs (functional value of price value for money). It is important to point out that Lee and Min (2013) have not included functional value of quality/ performance as it is claimed to be a relatively complex construct- perceived quality, which should be examined across multiple dimensions including site accessibility, extraconvention opportunity, site environment, social networking, professional education and staff service. Because this study strives to understand how convention attendees evaluate convention using perceived value but not perceived quality, in line with Lee and Min (2013), the present study considered only emotional, social and functional value of price/ value for the money dimensions of PERVAL scale when conceptualising perceived value. This decision is also made in view of the fact that the functional value of quality/ performance may overlap with the idea of value of co-creation that suggests quality is achieved by the intensity and interactions between firms and consumers (Schmidt, 2012). The description of the three perceived value dimensions that are deemed related to convention evaluation is 
explained as follows:

Emotional Value: Emotional value can be seen the utility derived from the feelings or affective states that the convention participation generates (Sweeney \& Soutar, 2001). Convention participation is likely to produce emotional value for participants as the gathering of like-minded people activates feelings and emotions for individuals that are involved (Butler, 2016; Mitchell et al., 2016). Specifically, it was found that communication, happiness and activation are important criteria to build an emotional attachment with convention participants (Mitchell et al., 2016; Trauner \& Ryan, 2005).

Functional Value (Price/ Value for Money): Functional value refers to the utility derived from the convention participation due to the reduction of costs (Sweeney \& Soutar, 2001). Value for money is expected to be the predictor of convention participants' attitude as the decision to travel for the convention implies monetary costs such as travelling expenses, accommodation and convention fees. This perceived value dimension is also critical in deciding convention participants' attitude as they tend to rely on economic evaluation on what they paid and received in return in judging the convention (Lee \& Min, 2013).

Social Value: Social value is the utility derived from the convention's ability to enhance a participants' social self-concept (Sweeney \& Soutar, 2001). In addition, social value is also associated with the self-image which convention participants wish to seek (Kim et al., 2012; Ryu \& Lee, 2013). This value dimension is expected to be generated by convention participation as participants get to meet up with people of different background to create and/ or consolidate professional connections as well as other types of relations, which will, in turn, enhance one's social standing (Mitchell et al., 2016).

In sum, we hypothesized that:

$\boldsymbol{H}_{1(a)}$ : Emotional value dimension of perceived value have a positive effect on convention attendees' attitude towards the convention. 
$\boldsymbol{H}_{1(b)}$ : Functional value dimension of perceived value have a positive effect on convention attendees' attitude towards the convention.

$\boldsymbol{H}_{1(c)}$ : Social value dimension of perceived value have a positive effect on convention attendees' attitude towards the convention.

According to Sánchez et al. (2006) and Yang and Roy (2013), despite the fact that perceived value is recognised as an important determinant in understanding consumer behavior, there is no universal conceptualisation of consumer value exists. With that being said, it is not certain if this one category of value is sufficient in predicting the consumer's value perception and subsequent behavior. Most of the literature portrayed values as relatively simple. It can be seen from the main bodies of perceived value related literature that value creation is a one-way process that is done by businesses for customers. In another word, businesses are solely responsible to create or add values to products and services offered, while customers receive and perceive these values (Vargo \& Lusch, 2004). In recent decades, scholars and practitioners started to recognise value in the context of customer experiences (Heinonen \& Strandvik, 2009). Specifically in the service industry, scholars posited that customers should not be treated only as recipients of products but they also hold power to engage in value co-creation process activity (Solakis et al., 2017).

\section{Value of Co-Creation and Attitude towards the Convention}

Prahalad and Ramaswamy (2004a) claimed that company-centric value creation would eventually become obsolete. In this ever-changing economy and business environments, marketers should not only focus on the products offered but should also devote their attention to personalised co-creation experiences that would result in values that are unique to consumers. As co-creation experience is gaining its role as a factor for successful company offerings, the academic literature focusing on the topic has developed quickly with most of them aimed at defining, conceptualising, explaining the theoretical underpinnings of 
the concept of customer experience and its effect on satisfaction (eg., Alves et al., 2016; Campos et al., 2018; Grissemann \& Stokburger-Sauer, 2012; Jaakkola et al., 2015; Navarro et al., 2016).

Despite the acknowledged importance of the concept from the organisation's perspective, the existing empirical work paid scant attention to the outcome of value cocreation from a customer's perspective (Hatch \& Schultz, 2010; Razak \& Marimuthu, 2012; Verleye, 2015). Only a number of articles found focusing on ascertaining the linkage between value co-creation and its outcome. Notably, it has been found that value of cocreation is positively related to customer loyalty because customers would perceive products that they co-created as unique and therefore, bring about a sense of competent and significant (Franke \& Schreier, 2008; Norton et al., 2012). Cossío-Silva et al. (2016) further highlight that customers' participation in joint value co-creation with the firm is related to both attitudinal (maintaining a positive attitude towards the product) and behavioral loyalty (repeated purchasing and engage in positive word-of-mouth). In another study, Xie et al. (2008) found value co-creation to be related to attitude and it would ultimately shape consumers" intention to engage in "pro-sumption" in the future. Along the same line, Kaur Sahi et al. (2017) also reported that value co-creation ultimately affects customers' recommendation of a service provider.

The concept of co-creation experience has provided a renewed way to consider the consumer consumption- a holistic experience which involves interaction between a consumer and a firm, or a firm's offer (Aquilani et al., 2017; LaSelle \& Britton, 2003). Accordingly, Prahalad and Ramaswamy (2004b, p. 8) highlighted that the concept of co-creation is all about "creating an experience environment in which customers can have active dialogue and co-construct personalised experienced... product may be the same but customers can construct different experience." Thus, based on this approach, it can be seen from the 
marketing trends today that the creation of value is partly based on the interaction between consumer and company, instead of merely on the memorability of staged experiences and events (Idros et al., 2019; LaSelle \& Britton, 2003). In the view of Prahalad and Ramaswamy (2004a), a company is responsible to provide contexts that support experience creation so that customers are able to co-create their personalised and unique experiences. In contrast to the traditional system in which the firms decide the product and services, and thus, the value, to the customers, value co-creation allows values to be jointly created by both the firms and the customers. In short, co-creation experience is what provides value in the contemporary business exchange (Binkhorst \& Den Dekker, 2009; Massi \& D'Angelo, 2020). Therefore, "high-quality interactions that enable an individual customer to co-create unique experiences with the company are the key to unlocking new sources of competitive advantage (Prahalad \& Ramaswamy, 2004b, p. 7)." The researchers further argue that value co-creation should be seen as a basis for value and future of innovation as the distinct role of the convention value creation (values contained by products or services) will eventually cease to exist as we move towards value co-creation.

Alhothali (2017) notes that both customer involvement in relevant processes and service outcomes are two critical elements that decide if a service is to be perceived as high value. It can be due to the fact that "the customer is always a co-creator of value. There is no value until an offering is used- experience and perception are essential to value determination (Vargo \& Lusch, 2006, p. 44)." Hence, following the theory of consumption values, cocreation experience, which is the basis for unique value for each consumer, can be seen as another form of values that consumer possessed, alongside with perceived value. Understanding value co-creation is paramount in the contemporary business world as "competition will centre on personalised co-creation experiences, resulting in values that are truly unique to each individual (Prahalad \& Ramaswamy, 2004b, p. 9).” Especially in the 
field of convention tourism, which is characterised with high-contact services, value of cocreation is expected to play a major role. Nonetheless, to our understanding, no existing research has integrated customers' value co-creation into the consumption values theory or event tourism studies. Therefore, its role in affecting traveller's attitude and subsequent behavior is unspecified.

In a past study, Navarro et al. (2014) has proven that value of co-creation can have a significant influence on hotel guests' attitude towards the service provider. This is because consumers' involvement and engagement in the product co-creation maylead to new product ideas and experience that they appreciate more (Hoyer et al., 2010) Furthermore, consumers' attitude is also enhanced as the product or service is likely to be compatible with their needs and wants (Franke et al., 2009). Similarly, Soltani et al. (2017) and Van Dijk et al. (2014) are also in support of the linkage between value of co-creation and consumers' attitude. On the other hand, the opportunity for consumers to co-create can also offer them a compelling experience that is "extremely gratifying" (Novak et al., 2000, p. 22), enjoyable and engaging. As a result, consumers' attitude is likely to be more favorable (Kohler et al., 2011; Piller \& Walcher, 2006). Following the argument, it is expected that value of co-creation will positively affect the attendees' attitude towards the event. Therefore, the following hypothesis is formulated:

$\boldsymbol{H}_{2}$ : Value of co-creation have a positive effect on convention attendees' attitude towards the convention.

Based on the hypotheses formulated, the following research model is illustrated in Figure 1.

**Insert Figure 1 Here**

\section{Methodology}

\section{Sample and Data Collection}


Data were collected by administering a survey to convention attendees who attended any international conventions held in Kuala Lumpur Convention Centre in Malaysia from July to October 2019. The respondents consist of business travellers from different parts of the world. According to Malaysia Convention \& Exhibition Bureau (2018), out of the 300 regional and international business events that they supported in 2018, the total number of delegates was estimated to be 350,303 , of which 162,623 were international delegates $(46 \%)$ and 187,680 domestic delegates $(54 \%)$. Therefore, the non-proportional quota sampling method was employed in this case, with the proportion of around 50 to 50 . Meanwhile, the selection process was carried out by convenience. That is, the selection of respondents was based on the ease with which the researcher and research assistants could access the attendees. The surveys were conducted at the main exits and hallways of the Kuala Lumpur Convention Centre on the last day of each of the events. The field researchers approached the convention attendees, outlined the purpose of the project and invited the attendees to take part in the research. Informed consent was obtained from each respondent, before they agreed to participate in the survey and were given the questionnaires. A total of 457 responses were collected. Due to missing information, 23 responses were eliminated. The final sample included 434 respønses for analyses.

\section{Measures}

This study examined the effect of perceived value and value of co-creation on convention attendees' attitude towards the convention. Perceived value (consisting of emotional, social and functional dimensions of value) was measured with 7-point Likert-type scales. The items used were adapted from the studies of Lee and Min (2013), which consists of 9 items $(1=$ strongly disagree to $7=$ strongly agree $)$.

In line with Ranjan and Read (2016), value of co-creation was conceptualised as a multidimensional concept that consists of two higher-order factors. Meanwhile, each of these 
two higher-order factors was made up of three sub-dimensions. The two factors are coproduction and value-in-use. Specifically, co-production was viewed as consisting of knowledge, equity and interactive, while value-in-use comprises of experience, personalisation and relationship. 23 items were adapted from Ranjan and Read (2016) and measured on a five-point Likert scale anchored as $1=$ strongly disagree to $5=$ strongly agree. As value of co-creation is a third order formative construct, 9 global indicators were included to validate the formative measurement of knowledge, equity, interaction, experience, personalisation, relationship, co-production, value-in-use and value of co-creation.

Lastly, 4 items were adapted from Song et al. (2014) to measure attendees' attitude towards the convention attended $(1=$ strongly disagree to $5=$ strongly agree $)$.

\section{Data Analysis}

Three steps were involved in analysing the data of this study. In the first step, the formative measurement model was assessed. Specifically, we examined the convergent validity using redundancy analysis, addressed collinearity issues by looking at the variance inflator factor (VIF) and assessed the significance and relevance of the formative indicators using average variance extracted (AVE). To establish the value of co-creation measurement model, which is of higher-order model, the repeated indicators approach was selected. This is because it is easy to implement, in which the researcher would assign all the indicators from the lower order constructs to the higher order constructs. Becker et al. (2012) also suggest that the repeated indicators approach should also be preferred over the two-stage approach as it produces more precise parameter estimates as well as a more reliable higher order construct score. Figures 2, 3 and 4 illustrate the specification of the hierarchical value of co-creation model using the repeated indicator approach in PLS-SEM. Hair et al. (2014) mentioned the repeated indicator approach is appropriate only if the model satisfies two criteria. Firstly, the number of indicators must be similar across the lower order constructs. This is because the 
inequality of number of indicators per lower order construct could lead to biased result (Becker et al., 2012). Secondly, all relevant validity and reliability criteria used for measurement model evaluation must be met. Meanwhile, the specific assessments used depend on the types of the measurement models - whether the lower order constructs and higher order constructs are reflectively or formatively measured. Considering the foregoing, the repeated indicator method is suitable for measuring value of co-creation in the present study. The number of indicators used is similar across the lower order constructs, ranging from 3 to 4 indicators. Also, all relevant validity and reliability criteria for measurement model evaluation are met and the results are presented in the following section.

In the second step, the reflective measurement models were assessed. Particularly, assessment on composite reliability (CR), indicator loadings, average variance extracted (AVE) and HTMT criterion were conducted in order to establish internal consistency, indicator reliability, factor loadings, convergent validity and discriminant validity, respectively. Finally, in the last step, the structural model was assessed. In order to reject or accept the hypotheses formulated, we examined the inner VIF, path coefficient, coefficient of determination, $f^{2}$ and $Q^{2}$.

**Insert Figure 2, 3 and 4 Here**

\section{Results}

\section{Demographic Characteristics}

The socio-demographic profiles of the sample are shown and summarised in Table 1. From the table, it can be seen that the sample has almost the equal size of male $(52.8 \%)$ and female (47.2\%). Majority of respondents were aged between 40 to 49 years $(41.2 \%)$ and completed their bachelor's degree. The table also shows that the largest group of respondents was Malaysians residing outside of Kuala Lumpur or Selangor (48.2\%).

$$
\text { **Insert Table } 1 \text { Here** }
$$




\section{Formative Measurement Model Assessment}

By using the repeated indicator approach, the exogenous variables in the first-order model are: knowledge, equity, interaction, experience, personalisation, and relationship. Meanwhile, co-production and value-in-use are the endogenous variables. For the secondorder model, the exogenous variables are co-production and value-in-use. Value of cocreation is the endogenous variable. Lastly, the exogenous variable in the third order model is value of co-creation and the endogenous variable is attitude towards the convention, which is reflectively measured. To establish convergent validity, redundancy analysis suggested by Chin (1998) was utilised. In particular, a new path model was created for each of the first order construct. The exogenous constructs were then drawn as formative mode to predict the relative global indicator. As shown in Table 2 all constructs yield path coefficients of more than 0.70 . Therefore, it can be concluded that all formatively measured constructs exhibit satisfactory to high satisfactory degree of convergent validity (Hair et al., 2017). On a different note, multi-collinearity between indicators was assessed by computing the variance inflation factor (VIF) score. Based on the result shown in Table 2, all indicators for the formative constructs satisfy the VIF values, in which they are all well below the thresholds of 5 (Hair et al., 2011) and 3.3 (Diamantopoulos \& Siguaw, 2006). Hence, the results indicate that there is no potential collinearity problem exists to affect the estimation of the PLS path model. Finally, the significance and relevance of the outer weights of the formative constructs were examined. As shown in Table 2, the results from bootstrapping indicate the outer weight from each formative indicator is significant at 0.05 . As a result, all indicators are retained in the formative constructs.

**Insert Table 2 Here**

\section{Reflective Measurement Model Assessment}


Four assessments were conducted, including internal consistency, indicator reliability, convergent validity and discriminant validity. The indicator loadings (to assess indicator reliability), composite reliability (to assess internal consistency) and average variance extracted (to assess convergent validity) are shown in Table 3. All four constructs met the minimum cut-off value for AVE and CR. In specific, the values of CR for all constructs are between 0.70 and 0.90, which can be considered satisfactory (Nunnally \& Bernstein, 1994). Furthermore, all AVE scores are greater than 0.50 (Hair et al., 2017). On a different note, all the loadings, except items EV2, EV3, and SV1, exceed the recommended value of 0.708 (Hair et al., 2017). Despite the low loadings, these three items were retained as the minimum of AVE result of 0.5 is achieved for each construct (Ramayah et al., 2018a).

Subsequently, the discriminant validity was examined performing HTMT inferential using the bootstrapping technique. As shown in Table 4, all the values are well below the criterion of $\mathrm{HTMT}_{0.90}$ (Gold et al., 2001) and $\mathrm{HTMT}_{0.85}$ (Kline, 2011). Additionally, the HTMT inferential results also show that the confidence interval does not show a value of 1 on any of the constructs (Henseler et al., 2015). Thus, the result substantiates that each construct in the model can better explain the variance of its own indicator rather than the variance of other construct. Therefore, at this stage, it can be concluded that the all constructs met the internal consistency, indicator reliability, convergent validity and convergent validity criteria.

$$
\begin{aligned}
& \text { **Insert Table } 3 \text { Here** } \\
& \text { **Insert Table } 4 \text { Here** }
\end{aligned}
$$

\section{Structural Model Assessment}

Having established the validity and reliability of the measurement models, this section assessed the predictive validity of perceived value and value of co-creation. The specific structural model is as shown in Figure 5.

\footnotetext{
**Insert Figure 5 Here**
} 
To test the significance level, $\mathrm{t}$-statistics for all paths were computed using the bootstrapping function of SmartPLS 3.0. Based on the results presented in Table 5, the path coefficients of all four relationships are found to have t-values greater than 1.645 and are significant at 0.01 and 0.05 levels of significance. The confidence intervals bias results further supported that all four relationships are significant as 0 does not straddle between the upper and lower bound results (Ramayah et al., 2018a). In particular, four predictors including emotional value $(\beta=0.101, \mathrm{p}<0.01)$, functional value $(\beta=0.240, \mathrm{p}<0.01)$, social value $(\beta=0.078, p<0.05)$ and value of co-creation $(\beta=0.394, p<0.01)$ are positively related to attitude towards the convention, which explain $38.6 \%$ of variances in attitude towards the convention. Therefore, all four relationships are supported. Furthermore, the adjusted $R^{2}$ value of 0.386 is greater than the value of 0.26 as suggested by Cohen (1988), indicating that this is a substantial model.

Next, the effect sizes, $f$ were examined. From Table 6 , it can be seen that emotional value (0.014) and social value (0.010) have trivial effects in producing the $R^{2}$ for attitude towards the convention. On a different note, functional value $(0.054)$ has a small effect, while value of co-creation (0.164) has a medium effect (Cohen, 1988). The predictive relevance of the model is further examined using the blindfolding procedure. As the $Q^{2}$ value for attitude towards the convention is larger than 0 , it can be concluded that the model has sufficient predictive relevance (Fornell \& Cha, 1994; Hair et al., 2017). Thus, it can be concluded that all research hypotheses are supported. For easier reference, Figure 6 illustrated the results of path estimates analysis.

**Insert Table 5 Here**

\section{Discussion and Implications}

As mentioned, the study result supports all hypotheses. Even though all perceived value dimensions and value of co-creation are important to convention attendees' in forming 
an attitude, value of co-creation is found to be the most important criteria among the others.

One possible explanation for this is that consumers today are increasingly willing to converse their needs and negotiate with companies (Prahalad \& Ramaswamy, 2004a). It can also be attributed to the fact that the "interaction between the firm and the consumer is becoming the locus of value creation and value extraction" (Prahalad \& Ramaswamy, 2004a, p. 5). This is especially true in this technologically advanced world when consumers are armed with connective tools that allow them to interact and co-create value with firms without time and place constraints. Consequently, consumers are able to create a personalised experience that suits their needs and of which they perceive as valuable (Franke et al., 2009). Importantly, the findings imply that convention attendees see more value in co-creation experience than the traditional pre-defined benefits (i.e. perceived value) arise from convention participation. In facilitating active collaboration and participation among convention attendees, convention organisers can make use of event technology such as voting tools and event gamification systems to encourage the sharing of knowledge and ideas before, during and after the event. From there, the organisers may adopt the information to the process of service provision and improve their convention accordingly. This is especially important as the value co-created can help convention organisers to identify micro-specialised competence at different stages of service delivery (Navarro et al., 2014). By tapping into attendees' perspective, convention organisers can also make immediate changes and refine their future events to enhance the experience. Ultimately, it may drive better return on investment.

Furthermore, functional value is found to be the second most important predictor in attitude formation. The finding is expected as for convention attendees, be it domestic or international business travellers, a trip to Kuala Lumpur involved substantial travelling costs and convention fees. Hence, the convention attendees are expected to make a rational economic assessment based on the quality of their convention experience (Sweeney \& 
Soutar, 2001). The findings, thus, substantiate that the convention tourism market is sensitive to price. Therefore, convention organisers have to ensure that their convention quality is not compromising. Furthermore, the organisers may also partner with the host destination and local sponsors in order to keep the costs down. Subsequently, they can meet the expectations of convention attendees and their affiliations by charging less for the convention fees.

Emotional value is another predictor that decide convention attendees' attitude. This finding can be connected to the remarks made by Lee and Min (2013) and Mitchell et al. (2016) that convention attendees cherish fun, pleasurable and interesting experience arise from event participation as these emotional and psychological benefits would affect their excitement and willingness to learn and exchange knowledge. Therefore, the organisers are recommended to organise and develop appropriate training programs regularly in order to build effective event facilitation teams that can generate positive convention atmosphere. Also, it is important for organisers to narrow down their target attendees to people who share the same characteristics, traits and even interests when marketing their events. This is because feelings and emotions of the convention attendees can also be activated when they get to meet up with other like-minded attendees whom they feel 'connected' to share woes and successes but not only commercial gain.

Meanwhile, the effect of social value dimension value may be negligible as the effect is trivial in causing a differential effect on attitude formation. This is explainable by the fact that socialising and widening professional network has become one of the most preliminary standards during convention attendees' perception process of consumer value. This can be supported by the view of Edelheim et al. (2018) and Mair (2014) who highlighted gathering like-minded individuals for a common object (including the exchange of ideas and views of a common topic) as the basic purpose of organising conventions. Thus, convention attendees may tend to take the social benefits for granted, making it a less significant predictor in the 
convention evaluation, while other factors playing a more significant role. As the convention industry tends to characterise with a socialising edge, social value creation should not be of main concern as long as the organisers deliver the basic features of the convention experience.

Taken together, the findings for the consumer value and attitude linkage is in line with the consumption values theory that claims individual value dimensions would make differential influence to consumers' choice (Sheth et al., 1991a). While the organisers are recommended to maximise the three most influential value factors (emotional value, functional value and value of co-creation), it may not be always practical. In such scenario, convention organisers should put more emphasis on value of co-creation related activities than functional and emotional values in order to "trade off less salient for more salient values" (Sheth et al., 1991b, p. 163). To sum up, the integration of value of co-creation into the consumption values theory in this study provides an alternative view in conceptualising consumer value, which posits that consumer satisfaction is determined by the service provider as well as the active involvement of consumers throughout the service delivery process.

\section{Conclusion}

To sum up, this study contributed to insights to the marketing of convention tourism by examining a model of the convention participation experiences and attitude formation with applicability at the academic and practical levels. It has been found that two dimensions of perceived value (functional and emotional values) and value of co-creation are important factors to predict convention evaluation among attendees. This study extended the understanding that perceived value by itself had limited effects in contributing the positive attitude towards conventions completely in the contemporary business world as consumers today are increasingly prefer co-creation of value and collaboration with service providers. 
Thus, the results confirmed that "consumers now seek to exercise their influence in every part of the business system... thereby 'co-create' value" (Prahalad \& Ramaswamy, 2004a, p. 6). Notwithstanding, this study entails several limitations. Firstly, this main focus of this study was limited to only convention attendees participating in conventions happening in Kuala Lumpur. Therefore, future works could replicate this model in the convention tourism context of a different country/ locations or even in another context such as leisure event tourism, environmental tourism, historical tourism, medical tourism and religious tourism.

Additionally, the study provided only static perspective on the topic and may not be effective in determining causal relationships between independent and dependent variables. In view of this, future studies may consider conducting longitudinal studies in order to enhance the generalizability of the information and improve the understanding of causal relationships among the variables. Finally, while the use of the quantitative method and closed-ended questions was sufficed for this study, future study works may opt for mixedmethod designs to explore convention attendees' perceptions, attitude and behavioural intention in more detail. 


\section{References}

Aamin, N. A. M., Ismail, H. N., \& Khalifah, Z. (2016). A conceptual study: Muslim tourists' perceived value in Sharia Compliant Hotes (SCH) in Malaysia. In S. M. Radzi, M. H. M. Hanafiah, N. Sumarjan, Z. Mohi, D. Sukyadi, K. Suryadi, \& P. Purnawarman (Eds.), Heritage, culture and society: Research agenda and best practices in the hospitality and tourism industry (pp. 765-771). CRC Press.

Ahmad, J., \& Daud, N. (2016). Determining innovative tourism event professional competency for conventions and exhibitions industry: A preliminary study. Procedia Social and Behavioral Sciences, 219, 69-75.

https://doi.org/10.1016/j.sbspro.2016.04.041

Alhothali, G. T. (2017). Interaction experiences and outcomes of value co-creation in banking in Saudi Arabia, Monash University.

Alves, H., Fernandes, C., \& Raposo, M. (2016). Value co-creation: Concept and contexts of application and study. Journal of Business Research, 69(5), 1626-1633. https://doi.org/10.1016/1.jbustes.2015.10.029

Anker, T. B., Sparks, L,, Møutinho, L., \& Grönroos, C. (2015). Consumer dominant value creation: A theoretical response to the recent call for a consumer dominant logic for marketing. European Journal of Marketing, 49(3/4), 532-560.

https://doi.org/10.1108/EJM-09-2013-0518

Aquilani, B., Nosi, C., \& Abbate, T. (2017). Co-creation emerging in markets and with consumers: Contrasting service-dominant logic and value co-creation. In S. Rozenes \& Y. Cohen (Eds.), Handbook of research on strategic alliances and value cocreation in the service industry (pp. 37-59). IGI Global. 
Becker, J.-M., Klein, K., \& Wetzels, M. (2012). Hierarchical latent variable models in plssem: guidelines for using reflective-formative type models. Long Range Planning, 45(5-6), 359-394. https://doi.org/10.1016/j.1rp.2012.10.001

Beneke, J., \& Carter, S. (2015). The development of a consumer value proposition of private label brands and the application thereof in a South African retail context. Journal of Retailing and Consumer Services, 25, 22-35. https://doi.org/10.1016/j.jretconser.2015.03.002

Binkhorst, E., \& Den Dekker, T. (2009). Agenda for co-creation tourism experience research. Journal of Hospitality Marketing \& Management, 18(2-3), 311-327. https://doi.org/10.1080/19368620802594193

Bradley, G. L., \& Sparks, B. A. (2012). Antecedents and consequences of consumer value: A longitudinal study of timeshare owners, Journal of Travel Research, 51(2), 191-204. https://doi.org/10.1177/0047287510396099

Butler, J. (2016). Predicting loyalty in clubs through motivation, perceived value, satisfaction, and place attachement. Graduate Theses and Dissertations. https://doi.org/10.31274/etd-180810-5513

Campos, A. C., Mendes, J., Valle, P. O. d., \& Scott, N. (2018). Co-creation of tourist experiences: A literature review. Current Issues in Tourism, 21(4), 369-400. https://doi.org/10.1080/13683500.2015.1081158

Chin, W. W. (1998). The partial least squares approach for structural equation modeling, Modern methods for business research (pp. 295-336). Lawrence Erlbaum Associates Publishers.

Choe, J. Y., \& Kim, S. (2018). Effects of tourists' local food consumption value on attitude, food destination image, and behavioral intention. International Journal of Hospitality Management, 71, 1-10. https://doi.org/10.1016/j.ijhm.2017.11.007 
Cohen, J. (1988). Statistical power analysis for the behavioral sciences. Lawrence Erlbaum Associates.

Cossío-Silva, F.-J., Revilla-Camacho, M.-Á., Vega-Vázquez, M., \& Palacios-Florencio, B. (2016). Value co-creation and customer loyalty. Journal of Business Research, 69(5), 1621-1625. https://doi.org/10.1016/j.jbusres.2015.10.028

Cronin, J. J., Brady, M. K., \& Hult, G. T. M. (2000). Assessing the effects of quality, value, and customer satisfaction on consumer behavioral intentions in service environments. Journal of Retailing, 76(2), 193-218. https://doi.org/10.1016/S0022-4359(00)00028-2

Diamantopoulos, A., \& Siguaw, J. A. (2006). Formative versus reflective indicators in organizational measure development: A comparison and empirical illustration. British Journal of Management, 17(4), 263-282. https://doi.org/10.1111/j.1467-

\section{$\underline{8551.2006 .00500 . \mathrm{x}}$}

Dowse, S., \& Fletcher, T. (2018). Sport mega-events, the 'non-west' and the ethics of event hosting. Sport in Society, $21(5), 745-761$. https://doi.org/10.1080/17430437.2018.1401359

Ducoffe, R. H. (1996). Advertising value and advertising on the web. Journal of Advertising Research, 36(5), 21-35.

Edelheim, J. R., Thomas, K., Åberg, K. G., \& Phi, G. (2018). What do conferences do? What is academics' intangible return on investment (ROI) from attending an academic tourism conference? Journal of Teaching in Travel \& Tourism, 18(1), 94-107. https://doi.org/10.1080/15313220.2017.1407517 
Events Industry Council, \& Oxford Economics. (2018). Global economic significance of business events. Event Industry Council.

https://insights.eventscouncil.org/Portals/0/OE-

EIC\%20Global\%20Meetings\%20Significance\%20\%28FINAL\%29\%202018-11-09-

$\underline{2018 . p d f}$

Fandos Roig, J. C,, Sanchez Garcia, J., Angel Moliner Tena, M., \& Llorens Monzonis, J. (2006). Customer perceived value in banking services. International Journal of Bank Marketing, 24(5), 266-283. https://doi.org/10.1108/02652320610681729

Fiore, A. M., Kim, J., \& Lee, H.-H. (2005). Effect of image interactivity technology on consumer responses toward the online retailer. Journal of Interactive Marketing, 19(3), 38-53. https://doi.org/10.1002/dir.20042

Fornell, C., \& Cha, J. (1994). Partial least squares. In R. P. Bagozzi (Ed.), Advanced methods of marketing research (pp. 52-78). Blackwell Publishers.

Franke, N., Keinz, P., \& Steger, C. J. (2009). Testing the value of customization: When do customers really prefer products tailored to their preferences? Journal of Marketing, 73(5), 103-121.https://døi.org/10.1509/jmkg.73.5.103

Franke, N., \& Schreier, M. (2008). Product uniqueness as a driver of customer utility in mass customization. Marketing Letters, 19, 93-107. https://doi.org/10.1007/s11002-007$\underline{9029-7}$

Getz, D. (2014). Timing tourism: Mice, events, and mega events. In A. A. Lew, C. M. Hall, \& A. M. Williams (Eds.), The Wiley blackwell companion to tourism (pp. 401-412). John Wiley \& Sons Ltd.

Gold, A. H., Malhotra, A., \& Segars, A. H. (2001). Knowledge management: An organizational capabilities perspective. Journal of Management Information Systems, 18(1), 185-214. https://doi.org/10.1080/07421222.2001.11045669 
Gonçalves, H. M., Lourenço, T. F., \& Silva, G. M. (2016). Green buying behavior and the theory of consumption values: A fuzzy-set approach. Journal of Business Research, 69(4), 1484-1491. https://doi.org/10.1016/j.jbusres.2015.10.129

Grissemann, U. S., \& Stokburger-Sauer, N. E. (2012). Customer co-creation of travel services: The role of company support and customer satisfaction with the co-creation performance. Tourism Management, 33(6), 1483-1492. https://doi.org/10.1016/j.tourman.2012.02.002

Gupta, A., Su, B.-c., \& Walter, Z. (2004). Risk profile and consumer shopping behavior in electronic and traditional channels. Decision Support Systems, 38(3), 347-367. https://doi.org/10.1016/j.dss.2003.08.002

Hair, J. F., Hult, G. T. M., Ringle, C. M., \& Sarstedt, M. (2017). A primer on partial least squares structural equation modeling (2nd Ed.).SSage. https://lib.ugent.be/catalog/rug01:002301564

Hair, J. F., Ringle, C. M., \& Sarstedt, M. (2011). PLS-SEM: Indeed a silver bullet. Journal of Marketing Theory and Practice, 19(2), 139-152. https://doi.org/10.2753/MTP1069$\underline{6679190202}$

Hair, J. F. J., Hult,G. T. M., Ringle, C. M., \& Sarstedt, M. (2014). A primer on partial least squares structural equation modeling (PLS-SEM). SAGE Publications, Inc.

Hansen, A. V. (2019). Value co-creation in service marketing: A critical (re)view. International Journal of Innovation Studies, 3(4), 73-83. https://doi.org/10.1016/j.ijis.2019.12.001

Hatch, M. J., \& Schultz, M. (2010). Toward a theory of brand co-creation with implications for brand governance. Journal of Brand Management, 17(8), 590-604. https://doi.org/10.1057/bm.2010.14 
Heinonen, K., \& Strandvik, T. (2009). Monitoring value-in-use of e-service. Journal of Service Management, 20(1), 33-51. https://doi.org/10.1108/09564230910936841

Henseler, J., Ringle, C. M., \& Sarstedt, M. (2015). A new criterion for assessing discriminant validity in variance-based structural equation modeling. Journal of the Academy of Marketing Science, 43(1), 115-135. https://doi.org/10.1007/s11747-014-0403-8

Holbrook, M. B. (1999). Consumer value a framework for analysis and research. Routledge. http://dx.doi.org/10.4324/9780203010679

Hoyer, W. D., Chandy, R., Dorotic, M., Krafft, M., \& Singh, S. S. (2010) Consumer cocreation in new product development. Journal of Service Research, 13(3), 283-296. https://doi.org/10.1177/1094670510375604

Idros, N. A. N. M., Mohamed, H., \& Jenal, R. (2019). Determinant factors of customer satisfaction for e-hailing service: a preliminary study. In F. Saeed, N. Gazem, F. Mohammed, \& A. Busalim (Eds.), Recent trends in data science and soft computing: proceedings of the 3rd international conference of reliable information and communication technology (IRICT 2018) (pp. 803-813). Springer.

Jaakkola, E., Helkkula, A., \& Aarikka-Stenroos, L. (2015). Service experience co-creation: Conceptualization, implications, and future research directions. Journal of Service Management, 26(2), 182-205. https://doi.org/10.1108/JOSM-12-2014-0323

Jung, Y.-H. (2011). Effects of the perceived value of convention \& exhibition visitors on their satisfaction, revisit and recommendation intention. The Journal of the Korea Contents Association 11(11), 145-155. https://doi.org/10.5392/JKCA.2011.11.11.145

Kamakura, W. A., \& Novak, T. P. (1992). Value-system segmentation: Exploring the meaning of LOV. Journal of Consumer Research, 19(1), 119-132. http://www.jstor.org/stable/2489193 
Kaur Sahi, G., Sehgal, S., \& Sharma, R. (2017). Predicting customers recommendation from co-creation of value, customization and relational value. Vikalpa: The Journal for Decision Makers, 42(1), 19-35. https://doi.org/10.1177/0256090916686680

Khalifa, A. S. (2004). Customer value: A review of recent literature and an integrative configuration. Management Decision, 42(5), 645-666. https://doi.org/10.1108/00251740410538497

Kim, S., Lee, J.-S., \& Kim, M. (2012). How different are first-time attendees from repeat attendees in convention evaluation? International Journal of Hospitality Management, 31(2), 544-553. https://doi.org/10.1016/j.ijhm.2011.07.014

Kim, Y. H., \& Kaewnuch, K. (2018). Finding the gaps in event management research: A descriptive meta-analysis. Event Management, 22(3), 453-467. https://doi.org/10.3727/152599518X15258922919408

Kline, R. B. (2011). Principles and practice of structural equation modeling ( $3^{\text {rd }} \mathrm{Ed}$.). Guilford Press.

Kohler, T., Fueller, J., Stieger, D., \& Matzler, K. (2011). Avatar-based innovation: Consequences of the virtual co-creation experience. Computers in Human Behavior, 27(1), 160-168. https://doi.org/10.1016/j.chb.2010.07.019

Kostelijk, E. (2017). The influence of values on consumer behaviour: The value compass. Routledge. https://doi.org/10.4324/9781315560045

LaSelle, D., \& Britton, T. A. (2003). Priceless: Turning ordinary products into extraordinary experiences. Harvard Business School Press.

Leach, M. P., Liu, A. H., \& Winsor, R. D. (2008). The impact of attitudes, word-of-mouth, and value congruence on conference participation: A comparison of attending and non-attending organizational members. Journal of Hospitality \& Leisure Marketing, 16(3), 246-269. https://doi.org/10.1080/10507050801946841 
Lee, J.-S., \& Min, C.-k. (2013). Examining the role of multidimensional value in convention attendee behavior. Journal of Hospitality \& Tourism Research, 37(3), 402-425. https://doi.org/10.1177/1096348012436383

Lee, Y.-K., Kim, S., Lee, C.-K., \& Kim, S.-H. (2014). The impact of a mega event on visitors' attitude toward hosting destination: Using trust transfer theory. Journal of Travel \& Tourism Marketing, 31(4), 507-521. https://doi.org/10.1080/10548408.2014.883347

Liao, J.-f., Chen, H.-q., \& Cai, P.-e. (2013). Study of "co-opetition" strategy in nonlinear environment. In E. Qi, J. Shen, \& R. Dou (Eds.), Proceedings of 20th international conference on industrial engineering and engineering: Theory and apply of industrial management. (pp. 1135-1144). Routledge.

Lin, Y.-M., Kao, S.-C., Tao, Y.-H., \& Wu, C. (2015). The role of consumption value and product types in repurchase intention of printed and online music products: The Taiwan's case. In L. Wang, S. Qesugi, I.-H. Ting, K. Okuhara, \& K. Wang (Eds.), Multidisciplinary social networks research: Second international conference, MISNC 2015Matsuyama, Japan, September 1-3, 2015 proceedings (pp. 16-29). SpringerVerlag.

Maggon, M., \& Chaudhry, H. (2018). Exploring relationships between customer satisfaction and customer attitude from customer relationship management viewpoint: An empirical study of leisure travellers. FIIB Business Review, 7(1), 57-65. https://doi.org/10.1177/2319714518766118

Mair, J. (2012). A review of business events literature. Event Management, 16(2), 133-141. https://doi.org/10.3727/152599512X13343565268339

Mair, J. (2014). Conferences and conventions: A research perspective. Routledge. https://doi.org/10.4324/9780203121740 
Malaysia Convention \& Exhibition Bureau. (2018). 2018 Annual Report

https://www.myceb.com.my/clients/Malaysia_Convention_and_Exhibition_Bureau 7 5E277C6-C63D-4DC3-89AC-

F6B30D21417D/contentms/img/pdf/Report/2018_myceb_annual_report.pdf

Massi, M., \& D'Angelo, A. (2020). Reversing heritage destruction through digital technology: The rekrei project. In D. Seychell, \& A. Dingli (Eds.), Rediscovering heritage through technology: A collection of innovative research case studies that are reworking the way we experience heritage (pp. 109-122). Springer.

McCartney, G. (2008). The CAT (casino tourism) and the MICE (meetings, incentives, conventions, exhibitions): Key development considerations for the convention and exhibition industry in Macao. Journal of Convention \& Event Tourism, 9(4), 293308. https://doi.org/10.1080/15470140802493380

McDougall, G. H. G. (2000). Customer satisfaetion with services: Putting perceived value into the equation. Journal of Services Marketing, 14(5), 392-410. https://doi.org/10.1108/08876040010340937

Mitchell, V.-W., Schlegelmilch,B. B., \& Mone, S.-D. (2016). Why should I attend? The value of business networking events. Industrial Marketing Management, 52, 100-108. https://doi.org/10.1016/j.indmarman.2015.05.014

Navarro, S., Andreu, L., \& Cervera, A. (2014). Value co-creation among hotels and disabled customers: An exploratory study. Journal of Business Research, 67(5), 813-818. https://doi.org/10.1016/j.jbusres.2013.11.050

Navarro, S., Llinares, C., \& Garzon, D. (2016). Exploring the relationship between cocreation and satisfaction using QCA. Journal of Business Research, 69(4), 13361339. https://doi.org/10.1016/j.jbusres.2015.10.103 
Nelson, R. R. (2010). Current issues in convention and exhibition facility development. The Haworth Press, Inc. https://doi.org/10.4324/9780203708286

Norton, M. I., Mochon, D., \& Ariely, D. (2012). The IKEA effect: When labor leads to love. Journal of Consumer Psychology, 22(3), 453-460.

https://doi.org/10.1016/j.jcps.2011.08.002

Novak, T. P., Hoffman, D. L., \& Yung, Y.-F. (2000). Measuring the customer experience in online environments: A structural modeling approach. Marketing Science, 19(1), 2242. https://doi.org/10.1287/mksc.19.1.22.15184

Nunnally, J. C., \& Bernstein, I. R. (1994). Psychometric theory. McGraw-Hill.

Oppermann, M., \& Chon, K.-S. (1997). Convention participation decision-making process. Annals of Tourism Research, 24(1), 178-191. https://doi.org/10.1016/S01607383(96)00049-7

Peña, A. I. P., Jamilena, D. M. F., \& Molina, M.A. R. (2012). The perceived value of the rural tourism stay and its effect on rural tourist behaviour. Journal of Sustainable Tourism, 20(8), 1045-1065. https://doi.org/10.1080/09669582.2012.667108

Peng, N., Chen, A., \& Hung, K.-P. (2019). Dining at luxury restaurants when traveling abroad: Incorporating destination attitude into a luxury consumption value model. Journal of Travel \& Tourism Marketing, 1-15. https://doi.org/10.1080/10548408.2019.1568352

Phau, I., Quintal, V., \& Shanka, T. (2014). Examining a consumption values theory approach of young tourists toward destination choice intentions. International Journal of Culture, 8(2), 125-139 https://doi.org/10.1108/IJCTHR-12-2012-0090

Piller, F. T., \& Walcher, D. (2006). Toolkits for idea competitions: A novel method to integrate users in new product development. $R \& D$ Management, 36(3), 307-318. https://doi.org/10.1111/j.1467-9310.2006.00432.x 
Prahalad, C. K., \& Ramaswamy, V. (2004a). Co-creation experiences: The next practice in value creation. Journal of Interactive Marketing, 18(3), 5-14. https://doi.org/10.1002/dir.20015

Prahalad, C. K., \& Ramaswamy, V. (2004b). Co-creating unique value with customers. Strategy \& Leadership, 32(3), 4-9. https://doi.org/doi:10.1108/10878570410699249

Prebensen, N. K., \& Xie, J. (2017). Efficacy of co-creation and mastering on perceived value and satisfaction in tourists' consumption. Tourism Management, 60, 166-176. https://doi.org/10.1016/j.tourman.2016.12.001

Prebensen, N. K., Woo, E., Chen, J. S., \& Uysal, M. (2013). Motivation and involvement as antecedents of the perceived value of the destination experience. Journal of Travel Research, 52(2), 253-264. https://doi.org/10.1177/0047287512461181

Ramayah, T., Cheah, J., F., C., Ting, H., \& Memon,M, A. (2018a). Partial least squares structural equation modelling (PLS-SEM) using SmartPLS 3.0. Pearson Malaysia Sdn Bhd.

Ramayah, T., Rahman, S. A., \& Ling,N. C. (2018b). How do consumption values influence online purchase intention among school leavers in Malaysia? Revista Brasileira de Gestão de Negócios, 20, 638-654. https://doi.org/10.7819/rbgn.v0i0.3139

Ramkissoon, H., Nunkoo, R., \& Gursoy, G. (2009). How consumption values affect destination image formation. In A. G. Woodside, C. M. Megehee, \& A. Ogle (Eds.), Perspectives on cross-cultural, ethnographic, brand image, storytelling, unconscious needs, and hospitality guest research (Advances In Culture, Tourism And Hospitality Research Volume 3) (pp. 143-168). Emerald Group Publishing Limited.

Ranjan, K. R., \& Read, S. (2016). Value co-creation: Concept and measurement. Journal of the Academy of Marketing Science, 44, 290-315. https://doi.org/10.1007/s11747-014$\underline{0397-2}$ 
Razak, N. S. A., \& Marimuthu, M. (2012). The relationship between co-creation value and Facebook shopping. Procedia - Social and Behavioral Sciences, 65, 768-774. https://doi.org/10.1016/j.sbspro.2012.11.197

Rokeach, M. (1972). Organization and change within value-attitude systems. In M. Rokeach (Ed.), Beliefs, attitudes, and values (pp. 156-178). Jossey-Bass.

Ruiz-Molina, M.-E., \& Gil-Saura, I. (2008). Perceived value, customer attitude and loyalty in retailing. Journal of Retail \& Leisure Property, 7, 305-314. https://doi.org/10.1057/rlp.2008.21

Russo, I., \& Confente, I. (2017). Customer loyalty and supply chain management: Businessto-business customer loyalty analysis. Routledge.

https://doi.org/10.4324/9781315162829

Ryu, K., \& Lee, J.-S. (2013). Understanding convention attendee behaviour from the perspective of self-congruity: The case of academic association convention. International Journal of Hospitality Management, 33, 29-40. https://doi.org/10.1016/.ijhm,2013.01.003

Sánchez, J., Callarisa, L., Rodríguez, R. M., \& Moliner, M. A. (2006). Perceived value of the purchase of a tourism product. Tourism Management, 27(3), 394-409. https://doi.org/10.1016/j.tourman.2004.11.007

Sánchez-Fernández, R., \& Iniesta-Bonillo, M. Á. (2007). The concept of perceived value: A systematic review of the research. Marketing Theory, 7(4), 427-451. https://doi.org/10.1177/1470593107083165

Sánchez-Fernández, R., Iniesta-Bonillo, M. Á., \& Holbrook, M. B. (2009). The conceptualisation and measurement of consumer value in services. International Journal of Market Research, 51(1), 1-17. https://doi.org/10.1177/147078530905100108 
Scaglione, A., \& Mendola, D. (2017). Measuring the perceived value of rural tourism: A field survey in the western Sicilian agritourism sector. Quality \& Quantity, 51, 745-763. https://doi.org/10.1007/s11135-016-0437-8

Schiffman, L., O’ Cass, A., Paladino, A., \& Carlson, J. (2014). Consumer behaviour (6 ${ }^{\text {th }}$ Ed.). Pearson Australia.

Schmidt, R. (2012). A framework for the suppor of value co-creation by social software. In F. Daniel, K. Barkaoui, \& S. Dustdar (Eds.), Business process management workshops (pp. 242-252). Springer-Verlag.

Sheth, J. N., Newman, B. I., \& Gross, B. L. (1991a). Consumption values and market choices. South-Western Publishing.

Sheth, J. N., Newman, B. I., \& Gross, B. L. (1991b). Why we buy what we buy: A theory of consumption values. Journal of Business Research, 22(2), 159-170. https://doi.org/10.1016/0148-2963(91)90050-8

Smith, J. B., \& Colgate, M. (2007), Customer value creation: A practical framework. Journal of Marketing Theory and Practice, 15(1), 7-23. https://doi.org/10.2753/MTP1069$\underline{6679150101}$

Solakis, K., Peña-Vinces, J. C., \& Lopéz-Bonilla, J. M. (2017). DART model from a customer's perspective: An exploratory study in the hospitality industry of greece. Problems and Perspectives in Management, 15(2), 536-548. https://doi.org/10.21511/ppm.15(si).2017.07

Soltani, M., Jandaghi, G., \& Forouzandeh Shahraki, P. (2017). Co-creation intention: Presenting a model of antecedents and its impact on attitude toward the product (case study in shatel company). Iranian Journal of Management Studies, 10(1), 143-174. https://doi.org/10.22059/ijms.2017.60244 
Song, H., You, G.-J., Reisinger, Y., Lee, C.-K., \& Lee, S.-K. (2014). behavioral intention of visitors to an oriental medicine festival: An extended model of goal directed behavior. Tourism Management, 42, 101-113. https://doi.org/10.1016/j.tourman.2013.11.003

Sung, E., \& Ozuem, W. (2018). Customer- perceived value of medical tourism (Medical tourism: Breakthroughs in research and practice (pp. 32-51). IGI Global.

Sweeney, J. C., \& Soutar, G. N. (2001). Consumer perceived value: The development of a multiple item scale. Journal of Retailing, 77(2), 203-220. https://doi.org/10.1016/S0022-4359(01)00041-0

Teo, H.-H., Oh, L.-B., Liu, C., \& Wei, K.-K. (2003). An empirical study of the effects of interactivity on web user attitude. International Journal of Human-Computer Studies, 58(3), 281-305. https://doi.org/10.1016/S1071-5819(03)00008-9

Trauner, B., \& Ryan, C. (2005). Destination image, romance and place experience- an application of intimacy theory in tourism. Tourism Management, 26(4), 481-491. https://doi.org/10.1016/j.tourman.2004.02.014

Van Dijk, J., Antonides, G., \& Schillewaert, N. (2014). Effects of co-creation claim on consumer brand perceptions and behavioural intentions. International Journal of Consumer Studies, 38(1), 110-118. https://doi.org/10.1111/ijcs.12071

Vargo, S. L., \& Lusch, R. F. (2004). Evolving to a new dominant logic for marketing. Journal of Marketing, 68(1), 1-17. https://doi.org/10.1509/jmkg.68.1.1.24036

Vargo, S. L., \& Lusch, R. F. (2006). Service-dominant logic: What it is, what it is not, what it might be. In R. F. Lusch \& S. L. Vargo (Eds.), The Service-dominant logic of marketing: Dialog, debate and direction (pp. 43-56).

Varki, S., \& Colgate, M. (2001). The role of price perceptions in an integrated model of behavioral intentions. Journal of Service Research, 3(3), 232-240. https://doi.org/10.1177/109467050133004 
Verleye, K. (2015). The co-creation experience from the customer perspective: Its measurement and determinants. Journal of Service Management, 26(2), 321-342. https://doi.org/doi:10.1108/JOSM-09-2014-0254

Wang, Y., Po Lo, H., Chi, R., \& Yang, Y. (2004). An integrated framework for customer value and customer-relationship-management performance: A customer-based perspective from China. Managing Service Quality: An International Journal, 14, 169-182. https://doi.org/10.1108/09604520410528590

Weber, K., \& Ladkin, A. (2003). The convention industry in australia and the united kingdom: Key issues and competitive forces. Journal of Travel Research, 42(2), 125132. https://doi.org/10.1177/0047287503257489

Weinstein, A., \& Johnson, W. C. (1999). Designing and delivering superior customer value: Concepts, cases, and applications. St. Lucie Press.

Wilkie, W. L. (1994). Consumer behaviour (3 $3^{\text {rd }}$ Ed.). Wiley.

Woodall, T. (2003). Conceptualising "value for the customer": An attributional, structural and dispositional analysis. Academy of Marketing Science Review, 1(12), 1-41. http://www.amsreview.org/articles/woodall12-2003.pdf

Xie, C., Bagozzi, R.P., \& Troye, S. V. (2008). Trying to prosume: Toward a theory of consumers as co-creators of value. Journal of the Academy of Marketing Science, 36(1), 109-122. https://doi.org/10.1007/s11747-007-0060-2

Yang, H.-P., \& Roy, S. K. (2013). Services marketing. In A. Gbadamosi, I. Bathgate, \& S. Nwankwo (Eds.), Principles of marketing: A value-based approach (pp. 283-304). Palgrave Macmillan.

Zauner, A., Koller, M., \& Hatak, I. (2015). Customer perceived value-conceptualization and avenues for future research. Cogent Psychology, 2(1). https://doi.org/10.1080/23311908.2015.1061782 
Zeithaml, V. A. (1988). Consumer perceptions of price, quality, and value: A means-end model and synthesis of evidence. Journal of Marketing, 52(3), 2-22.

https://www.jstor.org/stable/1251446 


\section{Table 1}

Respondent Demographic Characteristics $(\mathrm{N}=434)$

\begin{tabular}{|c|c|c|}
\hline $\begin{array}{l}\text { Demographic } \\
\text { Characteristics }\end{array}$ & Frequency & Percentage $(\%)$ \\
\hline \multicolumn{3}{|l|}{ Gender } \\
\hline Male & 229 & 52.8 \\
\hline Female & 205 & 47.2 \\
\hline \multicolumn{3}{|l|}{ Age } \\
\hline $20-29$ years & 40 & 9.2 \\
\hline $30-39$ years & 148 & 34.1 \\
\hline $40-49$ years & 179 & 41.2 \\
\hline $50-59$ years & 59 & 13.6 \\
\hline 60 years and above & 8 & 1.8 \\
\hline \multicolumn{3}{|l|}{ Education Qualification } \\
\hline Vocational school & 15 & 3.5 \\
\hline Bachelor's degree & 223 & 51.4 \\
\hline Master's degree & 157 & \\
\hline Doctoral degree & 39 & \\
\hline \multicolumn{3}{|l|}{ Place of Residence } \\
\hline Australia & 24 & \\
\hline Canada & 14 & 3.2 \\
\hline China/ Hong Kong & 18 & 4.1 \\
\hline Japan & 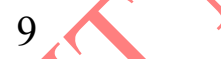 & 2.1 \\
\hline Korea & & 2.8 \\
\hline New Zealand & & 2.1 \\
\hline Singapore & & 7.1 \\
\hline Thailand & 5 & 1.2 \\
\hline United Kingdom & 6 & 1.4 \\
\hline The United States & 23 & 5.3 \\
\hline Malaysia (Outside of & 209 & 48.2 \\
\hline \multicolumn{3}{|l|}{ Kuala Lumpur or } \\
\hline \multicolumn{3}{|l|}{ Selangor) } \\
\hline Other Asian Countries & 43 & 9.9 \\
\hline Other European & 25 & 5.7 \\
\hline \multicolumn{3}{|l|}{ Countries } \\
\hline Other Countries & 6 & 1.4 \\
\hline
\end{tabular}




\section{Table 2}

\section{Results Summary for Formative Model Assessments}

\begin{tabular}{|c|c|c|c|c|c|c|c|c|c|c|c|c|c|c|c|c|c|c|c|c|}
\hline \multicolumn{7}{|c|}{ First-order Model } & \multicolumn{7}{|c|}{ Second-order Model } & \multicolumn{7}{|c|}{ Third-order Model } \\
\hline Construct & $\begin{array}{l}\text { Item } \\
\text { Code }\end{array}$ & $\begin{array}{l}\text { Convergent } \\
\text { Validity }\end{array}$ & $\begin{array}{l}\text { Weigh } \\
\text { ts }\end{array}$ & VIF & $\begin{array}{l}\text { t-value } \\
\text { weight } \\
\text { s } \\
\end{array}$ & Sig. & Construct & $\begin{array}{l}\text { Item } \\
\text { Code }\end{array}$ & $\begin{array}{l}\text { Convergent } \\
\text { Validity }\end{array}$ & Weights & VIF & $\begin{array}{l}\text { t-value } \\
\text { weights }\end{array}$ & Sig. & $\begin{array}{l}\text { Construc } \\
t\end{array}$ & $\begin{array}{l}\text { Item } \\
\text { Cod } \\
\text { e } \\
\end{array}$ & $\begin{array}{l}\text { Convergen } \\
\text { t Validity }\end{array}$ & $\begin{array}{l}\text { Weigh } \\
\text { ts }\end{array}$ & VIF & $\begin{array}{l}\text { t-value } \\
\text { weight } \\
\text { s } \\
\end{array}$ & Sig. \\
\hline \multirow[t]{4}{*}{ Knowledge } & KN1 & 0.717 & 0.377 & $\begin{array}{r}1.62 \\
2\end{array}$ & 9.228 & 0.000 & $\begin{array}{l}\text { Co- } \\
\text { Production }\end{array}$ & KN1 & 0.745 & 0.139 & 1.551 & 17.519 & 0.000 & $\begin{array}{l}\text { Value of } \\
\text { Co- } \\
\text { Creation }\end{array}$ & $\mathrm{KN} 1$ & 0.76 & 0.082 & 1.416 & 18.352 & 0.000 \\
\hline & $\mathrm{KN} 2$ & & 0.353 & $\begin{array}{r}1.58 \\
1\end{array}$ & 8.87 & 0.000 & & $\mathrm{KN} 2$ & & 0.14 & 1.54 & 19.216 & 0.000 & & $\mathrm{KN} 2$ & & 0.083 & 1.463 & 17.662 & 0.000 \\
\hline & $\mathrm{KN} 3$ & & 0.255 & $\begin{array}{r}1.52 \\
8\end{array}$ & 5.931 & 0.000 & & $\mathrm{KN} 3$ & & 0.124 & 1.465 & 15.079 & 0.000 & & $\mathrm{KN} 3$ & & 0.076 & 1.397 & 15.39 & 0.000 \\
\hline & $\mathrm{KN} 4$ & & 0.36 & $\begin{array}{r}1.41 \\
2\end{array}$ & 8.115 & 0.000 & & KN4 & & 0.131 & 1.353 & 17.041 & 0.000 & & KN4 & & 0.078 & 1.271 & 16.635 & 0.000 \\
\hline \multirow[t]{4}{*}{ Equity } & EQ1 & 0.849 & 0.311 & 1.53 & 7.646 & 0.000 & & EQ1 & & 0.134 & 1.469 & 17.595 & 0.000 & & EQ1 & & 0.08 & 1.4 & 16.339 & 0.000 \\
\hline & $\mathrm{EQ} 2$ & & 0.32 & $\begin{array}{r}1.82 \\
1\end{array}$ & 7.223 & 0.000 & & $\mathrm{EQ} 2$ & & 0.146 & 1.784 & 18.872 & 0.000 & & $\mathrm{EQ} 2$ & & 0.087 & 1.661 & 17.173 & 0.000 \\
\hline & EQ3 & & 0.302 & $\begin{array}{r}1.66 \\
8\end{array}$ & 7.539 & 0.000 & & EQ3 & & 0.138 & 1.6 & 18.679 & 0.000 & & EQ3 & & 0.083 & 1.513 & 17.777 & 0.000 \\
\hline & EQ4 & & 0.384 & $\begin{array}{r}1.55 \\
2 \\
\end{array}$ & 8.534 & 0.000 & & EQ4 & & 0.143 & 1.493 & 17.743 & 0.000 & & EQ4 & & 0.081 & 1.381 & 16.986 & 0.000 \\
\hline \multirow[t]{4}{*}{ Interaction } & IT1 & 0.815 & 0.319 & $\begin{array}{r}1.47 \\
8\end{array}$ & 8.548 & 0.000 & & IT1 & & 0.128 & 1.392 & 17.01 & 0.000 & & IT1 & & 0.076 & 1.319 & 15.685 & 0.000 \\
\hline & IT2 & & 0.362 & $\begin{array}{r}1.71 \\
3\end{array}$ & 9.65 & 0.000 & & IT2 & & 0.146 & 1.643 & 19.569 & 0.000 & & IT2 & & 0.089 & 1.544 & 18.499 & 0.000 \\
\hline & IT3 & & 0.331 & 1.71 & 8.425 & 0.000 & & IT3 & & 0.14 & 1.625 & 20.13 & 0.000 & & IT3 & & 0.087 & 1.521 & 19.784 & 0.000 \\
\hline & IT4 & & 0.316 & $\begin{array}{r}1.61 \\
3\end{array}$ & 7.74 & 0.000 & & IT4 & & 0.136 & 1.475 & 16.648 & 0.000 & & IT4 & & 0.085 & 1.4 & 17.95 & 0.000 \\
\hline \multirow[t]{3}{*}{ Experience } & EX1 & 0.901 & 0.458 & $\begin{array}{r}1.28 \\
3\end{array}$ & 8.878 & 0.000 & $\begin{array}{l}\text { Value-in- } \\
\text { Use }\end{array}$ & EX1 & 0.801 & 0.161 & 1.478 & 13.637 & 0.000 & & EX1 & & 0.084 & 1.187 & 15.264 & 0.000 \\
\hline & EX2 & & 0.398 & $\begin{array}{r}1.46 \\
6\end{array}$ & 7.426 & 0.000 & & $\mathrm{EX} 2$ & & 0.162 & 1.529 & 12.744 & 0.000 & & EX2 & & 0.083 & 1.318 & 14.369 & 0.000 \\
\hline & EX3 & & 0.473 & 1.47 & 9.084 & 0.000 & & EX3 & & 0.167 & 1.612 & 14.923 & 0.000 & & EX3 & & 0.084 & 1.224 & 16.399 & 0.000 \\
\hline \multirow[t]{4}{*}{$\begin{array}{l}\text { Personalisa } \\
\text { tion }\end{array}$} & PS1 & 0.902 & 0.452 & $\begin{array}{r}2.17 \\
3\end{array}$ & 9.145 & 0.000 & & PS1 & & 0.183 & 2.252 & 18.022 & 0.000 & & PS1 & & 0.093 & 1.918 & 19.48 & 0.000 \\
\hline & PS2 & & 0.234 & $\begin{array}{r}2.09 \\
4\end{array}$ & 4.659 & 0.000 & & PS2 & & 0.163 & 2.175 & 17.83 & 0.000 & & PS2 & & 0.084 & 2.044 & 17.59 & 0.000 \\
\hline & PS3 & & 0.369 & $\begin{array}{r}2.05 \\
4\end{array}$ & 8.063 & 0.000 & & PS3 & & 0.17 & 2.206 & 17.765 & 0.000 & & PS3 & & 0.092 & 1.94 & 17.859 & 0.000 \\
\hline & PS4 & & 0.212 & $\begin{array}{r}1.84 \\
6 \\
\end{array}$ & 4.23 & 0.000 & & PS4 & & 0.149 & 1.874 & 13.77 & 0.000 & & PS4 & & 0.078 & 1.777 & 13.945 & 0.000 \\
\hline \multirow[t]{4}{*}{$\begin{array}{l}\text { Relationshi } \\
\text { p }\end{array}$} & RS1 & 0.884 & 0.427 & $\begin{array}{r}2.17 \\
6\end{array}$ & 5.846 & 0.000 & & RS1 & & 0.145 & 2.246 & 13.086 & 0.000 & & RS1 & & 0.071 & 2.009 & 12.156 & 0.000 \\
\hline & $\mathrm{RS} 2$ & & 0.229 & $\begin{array}{r}2.11 \\
4\end{array}$ & 3.046 & 0.000 & & $\mathrm{RS} 2$ & & 0.132 & 2.177 & 11.167 & 0.000 & & $\mathrm{RS} 2$ & & 0.064 & 2.056 & 10.526 & 0.000 \\
\hline & RS3 & & 0.38 & $\begin{array}{r}1.99 \\
9\end{array}$ & 5.459 & 0.000 & & $\mathrm{RS} 3$ & & 0.136 & 2.107 & 12.586 & 0.000 & & RS3 & & 0.062 & 1.839 & 10.592 & 0.000 \\
\hline & RS4 & & 0.282 & 1.82 & 4.259 & 0.000 & & RS4 & & 0.133 & 1.915 & 11.945 & 0.000 & & RS4 & & 0.064 & 1.799 & 10.3 & 0.000 \\
\hline
\end{tabular}


Table 3

Results Summary for Reflective Measurement Models

\begin{tabular}{lllll}
\hline Construct & Item Code & Loadings & AVE & CR \\
\hline Emotional Value & EV1 & 0.920 & 0.547 & 0.777 \\
& EV2 & 0.666 & & \\
& EV3 & 0.592 & & \\
\hline Functional Value & FV1 & 0.837 & 0.712 & 0.881 \\
& FV2 & 0.873 & & \\
& FV3 & 0.820 & & \\
\hline Social Value & SV1 & 0.676 & 0.558 & 0.790 \\
& SV2 & 0.800 & & \\
\hline Attitude Towards the & SV3 & 0.759 & & 0.841 \\
Convention & AC2 & 0.729 & 0.569 & \\
& AC3 & 0.769 & & \\
& AC4 & 0.762 & & \\
\hline
\end{tabular}


Table 4

Results of Discriminant Validity Assessment Using HTMT Criterion (Investigation Part 1)

\begin{tabular}{|c|c|c|c|c|}
\hline & $\begin{array}{l}\text { Emotional } \\
\text { Value }\end{array}$ & $\begin{array}{l}\text { Functional } \\
\text { Value }\end{array}$ & Social Value & $\begin{array}{l}\text { Attitude } \\
\text { Towards the } \\
\text { Convention }\end{array}$ \\
\hline $\begin{array}{l}\text { Emotional } \\
\text { Value }\end{array}$ & & & & \\
\hline $\begin{array}{l}\text { Functional } \\
\text { Value }\end{array}$ & $\begin{array}{l}0.478 \\
\mathrm{CI}_{0.85}(0.389 \\
0.568)\end{array}$ & & & \\
\hline Social Value & $\begin{array}{l}0.123 \\
\mathrm{CI}_{0.85}(0.059 \\
0.162)\end{array}$ & $\begin{array}{l}0.187 \\
\mathrm{CI}_{0.85}(0.095, \\
0.287)\end{array}$ & & \\
\hline $\begin{array}{l}\text { Attitude } \\
\text { Towards the } \\
\text { Convention }\end{array}$ & $\begin{array}{l}0.353 \\
\mathrm{CI}_{0.85}(0.235 \\
0.444)\end{array}$ & $\begin{array}{l}0.682 \\
\mathrm{CI}_{0.85}(0.597, \\
0.760)\end{array}$ & $\begin{array}{l}0.192 \\
\mathrm{CI}_{0.85}(0.109, \\
0.286)\end{array}$ & \\
\hline
\end{tabular}

Note: Discriminant validity established at $\mathrm{HTMT}_{0.85}$ 


\section{Table 5}

Result of Relationship Testing Among Constructs

\begin{tabular}{|c|c|c|c|c|c|c|c|c|c|c|}
\hline \multirow[t]{2}{*}{ Hypothesis } & \multirow[t]{2}{*}{ Relationship } & \multirow[t]{2}{*}{$\begin{array}{l}\text { Std. } \\
\text { Beta }\end{array}$} & \multirow[t]{2}{*}{$\begin{array}{l}\text { Std. } \\
\text { Error }\end{array}$} & \multirow[t]{2}{*}{$\begin{array}{l}\text { t-value } \\
\text { (p values) }\end{array}$} & \multicolumn{2}{|c|}{$\begin{array}{l}\text { Confidence } \\
\text { Intervals Bias } \\
\text { Corrected } \\
\text { Result }\end{array}$} & \multirow[t]{2}{*}{ Decision } & \multirow[t]{2}{*}{$\begin{array}{l}\text { Adjusted } \\
R^{2}\end{array}$} & \multirow[t]{2}{*}{$f^{2}$} & \multirow[t]{2}{*}{$Q^{2}$} \\
\hline & & & & & $\begin{array}{l}\text { Upper } \\
\text { Bound } \\
(5 \%)\end{array}$ & $\begin{array}{l}\text { Lower } \\
\text { Bound } \\
(95 \%) \\
\end{array}$ & & & & \\
\hline $\mathrm{H}_{1(\mathrm{a})}$ & $\begin{array}{l}\text { Emotional Value -> } \\
\text { Attitude Towards the } \\
\text { Convention }\end{array}$ & 0.101 & 0.041 & $\begin{array}{l}2.487 * * \\
(0.007)\end{array}$ & 0.039 & 0.169 & Supported & 0.386 & 0.014 & 0.208 \\
\hline $\mathrm{H}_{1(\mathrm{~b})}$ & $\begin{array}{l}\text { Functional Value -> } \\
\text { Attitude Towards the } \\
\text { Convention }\end{array}$ & 0.240 & 0.051 & $\begin{array}{l}4.747 * * \\
(0.000)\end{array}$ & 0.158 & 0.319 & Supported & & 0.054 & \\
\hline $\mathrm{H}_{1(\mathrm{c})}$ & $\begin{array}{l}\text { Social Value }->\text { Attitude } \\
\text { Towards the Convention }\end{array}$ & 0.078 & 0.087 & $\begin{array}{l}2.159^{*} \\
(0.016) \\
\end{array}$ & 0.029 & 0.141 & Supported & & 0.010 & \\
\hline $\mathrm{H}_{2}$ & $\begin{array}{l}\text { Value of Co-creation -> } \\
\text { Attitude Towards the } \\
\text { Convention }\end{array}$ & 0.394 & 0.047 & $\begin{array}{l}8.383^{* *} \\
(0.000)\end{array}$ & 0.313 & 0.472 & Supported & & 0.164 & \\
\hline
\end{tabular}

Note: ${ }^{* *} p<0.01,{ }^{*} p<0.05$ 


\section{Figure 1}

Research Model

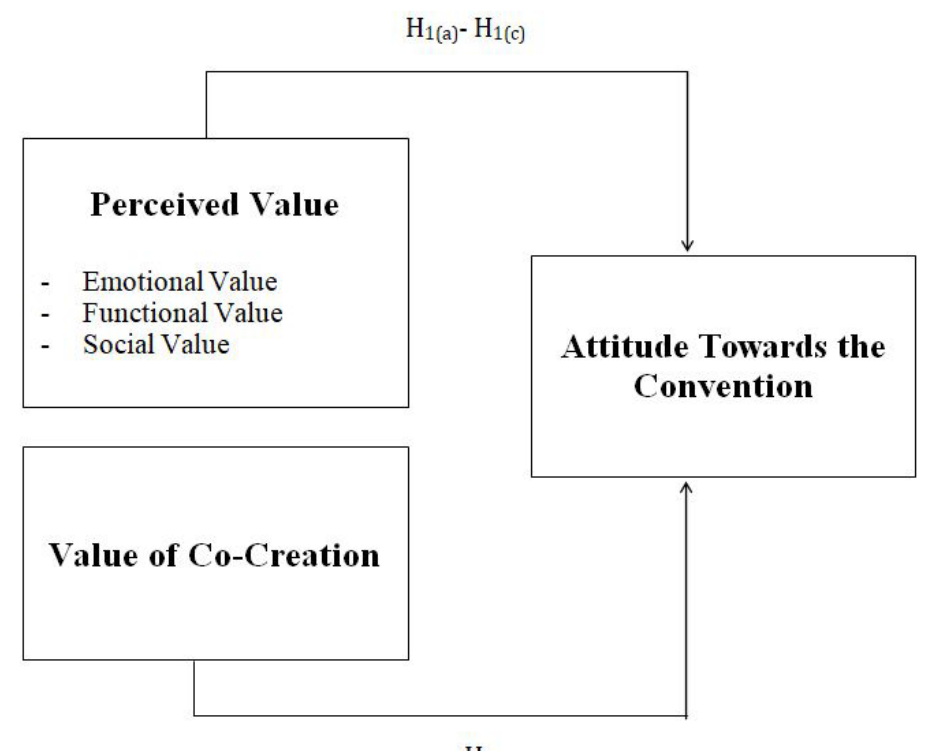

$\mathrm{H}_{2}$ 


\section{Figure 2}

First order latent variables of co-production and value-in-use

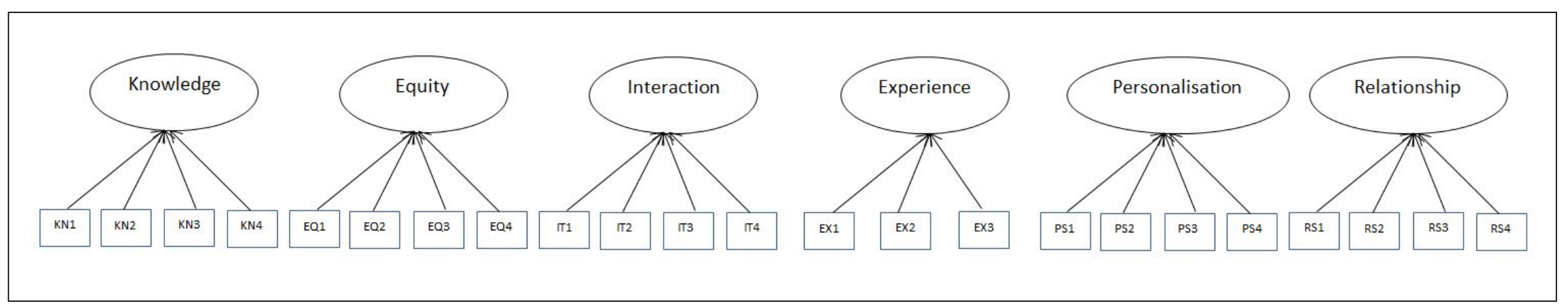

Note: First-order, formative latent variables (knowledge, equity, interaction, experience, personalisation and relationship) of co-production and value-in-use, which are related to their respective manifest variables (KN1-4; EQ1-4; IT1-4; EX1-3; PS1-4; RS1-4). 


\section{Figure 3}

Co-production and value-in-use as second order formative constructs

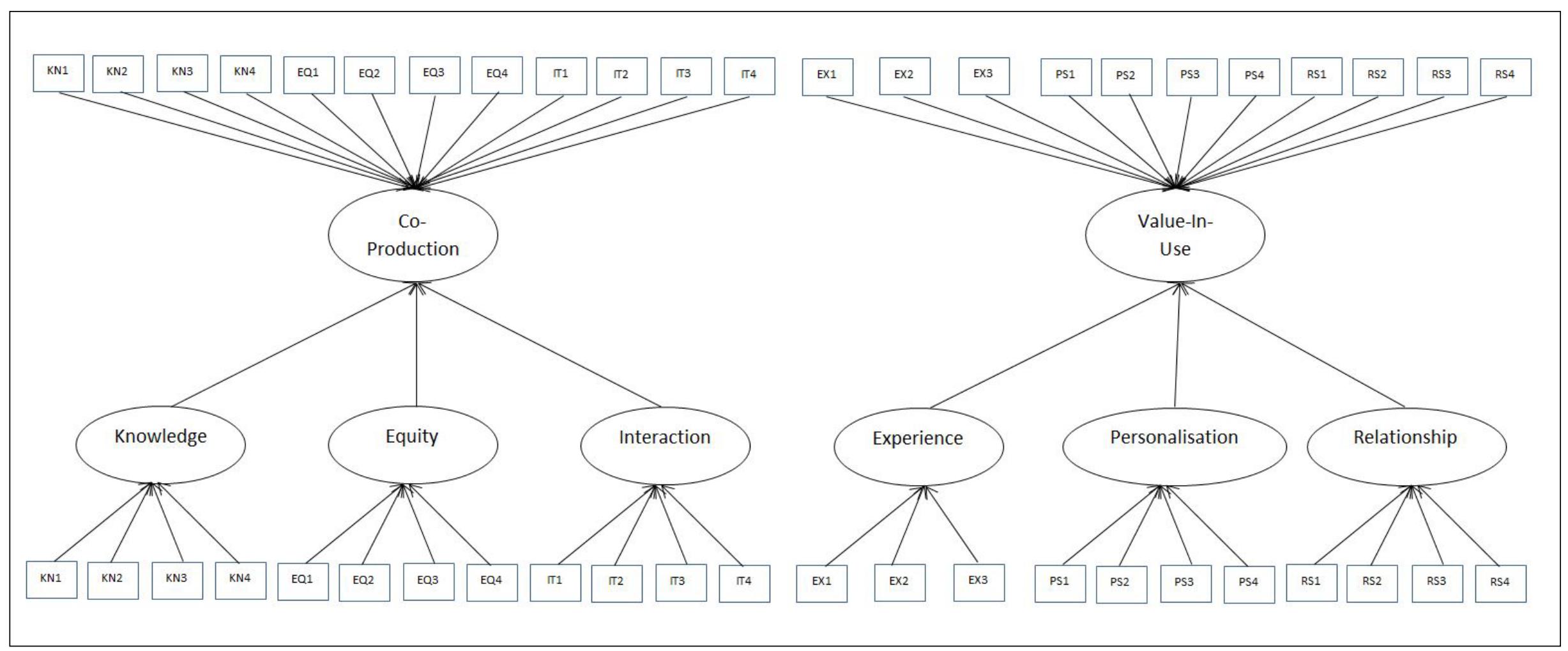

Note: Co-production and value-in-use as second order, formative variables, which are constructed by relating each of them to the blocks of the underlying first order latent variables. In particular, co-production is constructed by using 12 manifest variables $(4+4+4)$ of the first three latent variables. Meanwhile, value-in-use is constructed using 11 manifest variables $(3+4+4)$ of the next three latent variables. 


\section{Figure 4}

Value of co-creation as a third-order hierarchical formative construct

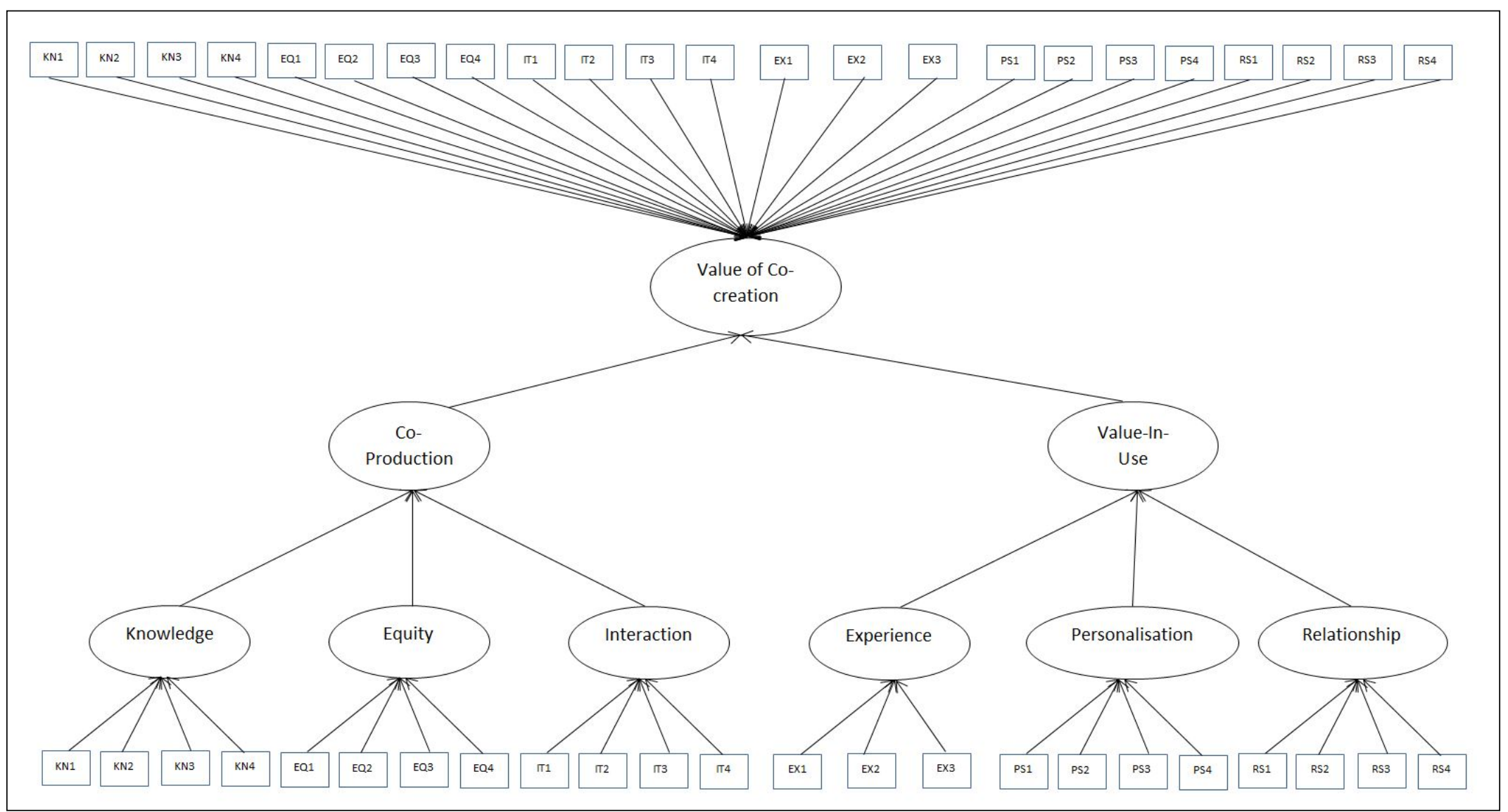

Note: Value of co-creation as a third order, formative variable, which is constructed by using all the manifest variables (23 manifest variables) of the 2 second order latent variables. In specific, value of co-creation is constructed by co-production (12 manifest variables) and value-in-use (11 manifest variables). Thus, value of co-creation is reflected by $23(12+11)$ manifest variables 


\section{Figure 5}

\section{Structural Model of the Study}

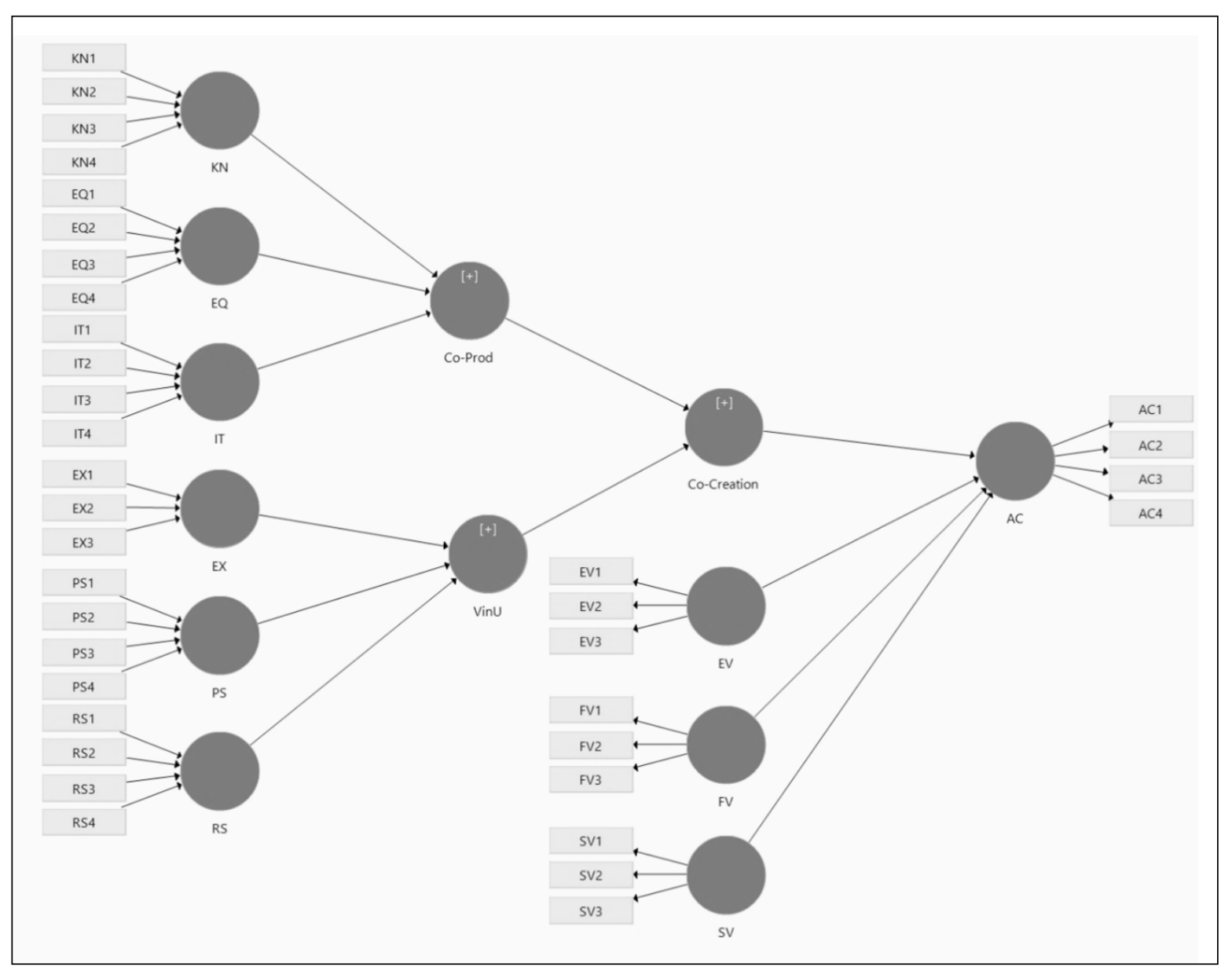

Note: $\mathrm{KN}=$ Knowledge, EQ= Equity, IT= Interaction, EX= Experience, $\mathrm{PS}=$ Personification, $\mathrm{RS}=$ Relationship, Co-Prod= Co-production, VinU= Value-in-use, $\mathrm{VCC}=$ Value of co-creation, $\mathrm{EV}=$ Emotional value, $\mathrm{FV}=$ Functional value, $\mathrm{SV}=$ Social value, $\mathrm{AC}=\mathrm{Attitude}$ towards the convention 


\section{Figure 6}

Results of the Path Estimates Analysis

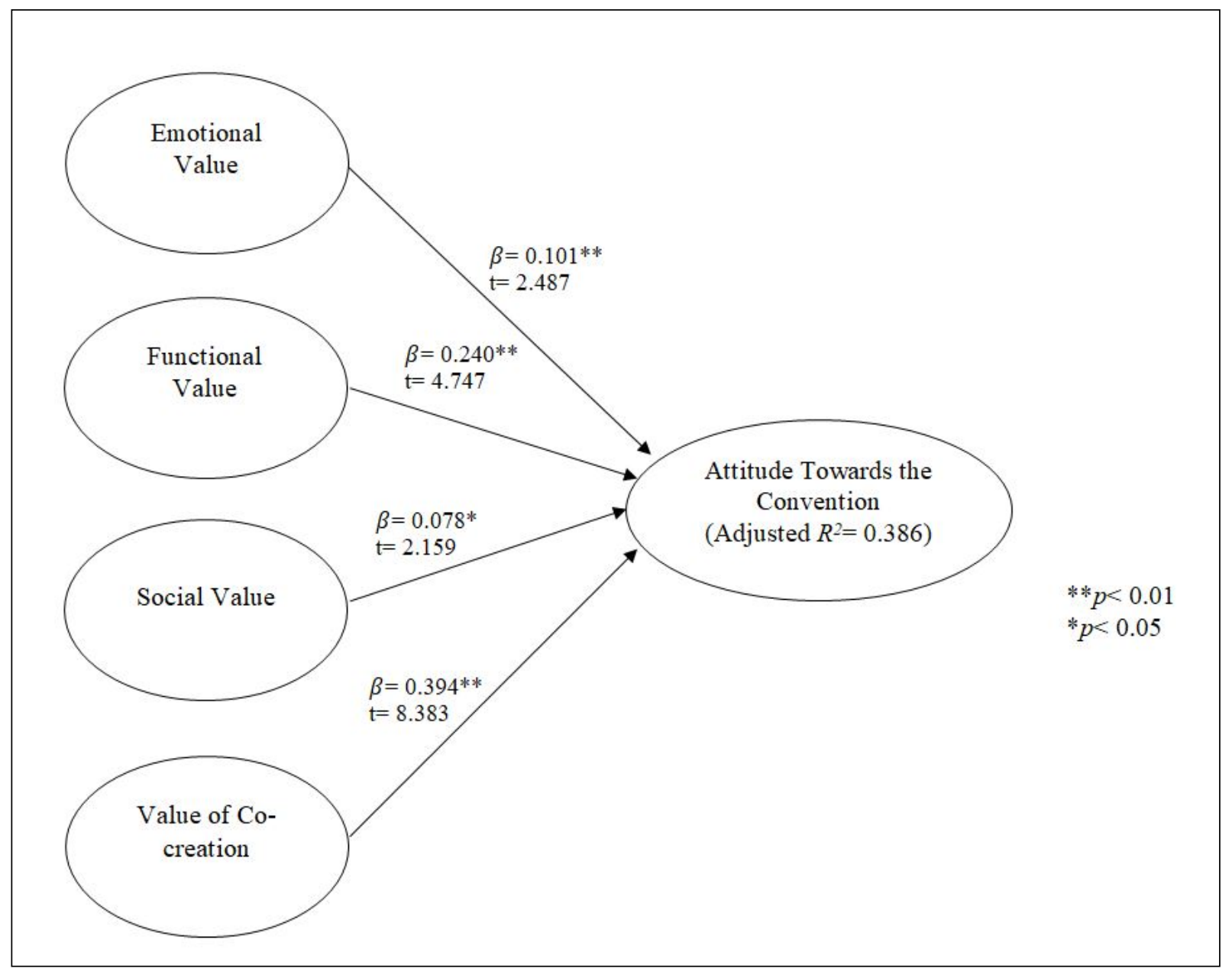

